\title{
Growth and gas exchanges of arugula plants under silicon fertilization and water restriction
}

\author{
Edmar G. de Jesus ${ }^{1}$, Reynaldo T. de Fatima ${ }^{1}$, Amaralina C. Guerrero ${ }^{1}$, \\ Josinaldo L. de Araújo ${ }^{1} \&$ Marcos E. B. Brito ${ }^{2}$ \\ ${ }^{1}$ Universidade Federal de Campina Grande/Centro de Ciências e Tecnologia Agroalimentar/Unidade Acadêmica de Ciências Agrárias. Pombal, \\ PB. E-mail: edmar.gj@gmail.com; reynaldo.t16@gmail.com; maracguerrero@gmail.com (Corresponding author); jhosinal_araujo@yahoo.com.br \\ ${ }^{2}$ Universidade Federal de Sergipe/Centro de Ciências Agrárias do Sertão/ Núcleo de Graduação em Educação em Ciências Agrárias e da Terra. Nossa \\ Senhora da Glória, SE. E-mail: marcosericbb@yahoo.com.br
}

\section{Key words:}

Eruca sativa Miller

water use efficiency silicon

\begin{abstract}
A B S T R A C T
The objective of this article was to study the growth and gas exchange of arugula plants under silicon $(\mathrm{Si})$ fertilization and water stress. The experiment was installed in a greenhouse, located in the municipality of Pombal, PB, Brazil, whose geographic coordinates are $6^{\circ} 46$ 'S latitude and $37^{\circ} 49^{\prime}$ W longitude and $178 \mathrm{~m}$ of altitude, situated in the 'Sertão Paraibano' micro-region. The experimental design was in randomized blocks, in $5 \times 2$ factorial scheme, corresponding to five $\mathrm{Si}$ doses $\left(0,50,100,150\right.$ and $\left.200 \mathrm{mg} \mathrm{L}^{-1}\right)$ and two irrigation depths [50 and $100 \%$ of real evapotranspiration (ETr) based on weighing lysimeter], with four replicates. Silicon application was performed as foliar spray, using a commercial product composed of $0.75 \% \mathrm{Si}$ and $0.15 \% \mathrm{Mo}$. Arugula growth and gas exchange was evaluated. Higher values for number of leaves and plant height were obtained in plants cultivated under $100 \% \mathrm{ETr}$. Silicon application between 100 and $120 \mathrm{mg} \mathrm{L}^{-1}$ led to better results in the physiological variables of arugula plants under water stress. Silicon application between 30 and $60 \mathrm{mg} \mathrm{L}^{-1}$ in arugula plants under $100 \% \mathrm{ETr}$ irrigation allowed greater phytomass accumulation.
\end{abstract}

\section{Palavras-chave: \\ Eruca sativa Miller eficiência no uso da água silício}

\section{Crescimento e trocas gasosas de rúcula sob adubação silicatada e restrição hídrica}

\section{R E S U M O}

Objetivou-se estudar o crescimento e as trocas gasosas de plantas de rúcula sob adubação com silício e estresse hídrico. O experimento foi instalado em casa de vegetação, localizada no município de Pombal, PB, Brasil, cujas coordenadas geográficas são $06^{\circ} 46^{\prime} \mathrm{S}$ de latitude e $37^{\circ} 49^{\prime}$ W de longitude e 178 m de altitude, localizada na microrregião do Sertão Paraibano. O delineamento experimental de blocos casualizados, com tratamentos arranjados em esquema fatorial $5 \times 2$, relativos a cinco doses de $\mathrm{Si}\left(0,50,100,150\right.$ e $\left.200 \mathrm{mg} \mathrm{L}^{-1}\right)$ e duas lâminas de irrigação [50 e 100\% da evapotranspiração real (ETr) baseada em lisímetro de pesagem], com quatro repetições. A aplicação do Si foi feita via foliar, utilizando-se um produto comercial composto por $0,75 \%$ de Si e $0,15 \%$ de Mo. Avaliou-se o crescimento e as trocas gasosas da rúcula. Maiores valores para número de folhas e altura de plantas foram obtidos nas plantas cultivadas com lâmina de $100 \%$ da ETr. A aplicação de silício entre 100 e $120 \mathrm{mg} \mathrm{L}^{-1}$ proporcionou melhores resultados nas variáveis fisiológicas de plantas de rúcula sob estresse hídrico. A aplicação de silício entre 30 e $60 \mathrm{mg} \mathrm{L}^{-1} \mathrm{em}$ plantas de rúcula sob irrigação com $100 \%$ da ETr possibilitaram maior acúmulo de fitomassa. 


\section{INTRODUCTION}

Arugula is a vegetable used in human diet and has been planted in various regions of Brazil. It is one of the most nutritious vegetables, containing minerals such as potassium, sulfur and iron, besides vitamins A and C (Porto et al., 2013). Its cultivation is mainly concentrated among medium and small farmers, which gives it economic and social importance, being a factor of aggregation between man and field (Souza Neta et al., 2013), which makes it a potential crop for cultivation in the semi-arid region.

Nonetheless, water balance is negative in this region, i.e., the evapotranspiration potential is higher than the rainfall. Thus, arugula cultivation can only be viable using irrigation, which generates, besides costs with the irrigation system, environmental problems due to the low quality of the irrigation water, for instance, the salinization of agricultural areas. Therefore, it is important to use strategies to improve water use.

Strategies include the use of silicon (Si), which has been identified as an element that attenuate abiotic stress factors (Souza et al., 2013; Teodoro et al., 2015). Using Si in agriculture has various benefits to plants, such as the increase of yield, tolerance to attacks of pests and diseases, decrease in the effects of toxic metals and tolerance to salt and water stresses (Rodrigues et al., 2011).

Most beneficial effects of $\mathrm{Si}$ in reducing water stress are attributed to the deposition of $\mathrm{Si}$ on the cell walls of roots, leaves and stem. Such deposition increases the resistance and hardness of the cell walls, reduces cuticle transpiration and increases the resistance to lodging and drought (Ma \& Yamagi, 2006).

To verify whether the use of Si in arugula plants can minimize the effects of water stress and allow improvement in water use, various physiological indices can be used, including photosynthesis, stomatal conductance and water use efficiency, since an osmotic adjustment, such as stomatal closure, allows plants to escape from dehydration and loss of turgor through the maintenance of water content in the cells.

Hence, this study aimed to investigate the morphophysiological effects on the growth and gas exchanges of arugula plants cultivated under Si doses and water stress.

\section{Material AND Methods}

The experiment was installed in a greenhouse at the Center of Sciences and Agri-Food Technology of the Federal University of Campina Grande (CCTA/UFCG), Campus of Pombal, PB, Brazil, whose geographic coordinates are $06^{\circ} 46^{\prime}$ S latitude and $37^{\circ} 49^{\prime} \mathrm{W}$ longitude, $178 \mathrm{~m}$ of altitude, located in the Sertão Paraibano micro-region.

The experimental design was randomized blocks, with treatments arranged in a $5 \times 2$ factorial scheme, which corresponded to five Si doses (0, 50, 100, 150 and $\left.200 \mathrm{mg} \mathrm{L}^{-1}\right)$ and two irrigation depths [50\% Real evapotranspiration (ETr) and $100 \% \mathrm{ETr}$ ], with four replicates. Each experimental unit was composed of a $4 \mathrm{~L}$ pot filled with samples from a Fluvic Neosol with sandy loam texture, collected in the $0-20 \mathrm{~cm}$ layer.

The soil, after air-dried, pounded to break up clods and sieved through a $2.0 \mathrm{~mm}$ mesh, was sent to the Laboratory of Soil and Plant Analyses of the CCTA/UFCG for chemical characterization, according to procedures described in EMBRAPA (1997). The material showed the following attributes of fertility: $\mathrm{pH}=6.02 ; \mathrm{P}=10 \mathrm{mg} \mathrm{dm}{ }^{-3} ; \mathrm{H}^{+}+\mathrm{Al}^{3+}=$ $0.0 \mathrm{mmol} \mathrm{dm}{ }^{-3} ; \mathrm{K}^{+}=0.41 \mathrm{mmol} \mathrm{dm}^{-3} ; \mathrm{Ca}^{2+}=4.15 \mathrm{mmol}_{c} \mathrm{dm}^{-3}$; $\mathrm{Mg}^{2+}=7.05 \mathrm{dm}^{-3} ; \mathrm{Na}^{+}=0.15 \mathrm{mmol}_{\mathrm{c}} \mathrm{dm}^{-3} ; \mathrm{Si}=1.95 \mathrm{mg} \mathrm{dm}^{-3} ;$ sum of bases $=11.76 \mathrm{mmol}_{\mathrm{c}} \mathrm{dm}^{-3}$ and base saturation $(\mathrm{V})=100 \%$.

Si doses were applied in the form of a commercial product, Silamol, which contains $0.75 \%$ Si and $0.15 \%$ molybdenum (Mo), as foliar spray, every week, starting at 7 days after transplantation, in a total of three applications. Mo doses were compensated using ammonium molybdate so that all solutions of foliar application with Silamol had the same Mo concentrations. The concentrations of the solutions for each treatment were: $0,6.71,13.43,20.1$ and $26.7 \mathrm{~mL}$ of Silamol diluted in public-supply water until reaching the volume of 1 L. Applications were performed with a $1.5 \mathrm{~L}$ manual sprayer, using $13.88 \mathrm{~mL}$ of the solution for each plant every seven days.

Real evapotranspiration was determined using the weighing lysimetry method in the treatments under $100 \%$ ETr. For that, pot weight at field capacity $\left(\mathrm{W}_{\mathrm{FC}}\right)$ was determined based on saturation by capillarity followed by drainage until constant weight, and each pot was daily weighed to obtain the current weight $\left(\mathrm{W}_{\mathrm{C}}\right)$. These data were used in Eq. 1 to determine ETr, by dividing the subtraction of these values by the area of the pot. Plants under $50 \%$ ETr received $50 \%$ of the water volume applied in plants under $100 \%$ ETr.

$$
\mathrm{LI}_{10 \mathrm{oETr}}=\frac{\mathrm{Pcc}-\mathrm{Pa}}{\mathrm{A}}
$$

Fertilizations with macronutrients (except nitrogen) and micronutrients were applied as recommended by Malavolta et al. (1997). The quantities of nutrients used were: $\mathrm{P}=1.92 \mathrm{mg}$ $\mathrm{dm}^{-3} ; \mathrm{K}=64.7 \mathrm{mg} \mathrm{dm}^{-3} ; \mathrm{N}=35.6 \mathrm{mg} \mathrm{dm}^{-3}$, and nitrogen was split into four applications to avoid losses through leaching and to ensure that it did not cause any damage to the plant. 1.7 $\mathrm{mg} \mathrm{dm}{ }^{-3}$ of $\mathrm{Ca}^{2}$ was applied along with $\mathrm{P}$ as basal fertilization. $\mathrm{Mg}$ fertilization was not necessary because the content in the soil was adequate for the crop. As mineral sources, the following fertilizers were used, respectively: Urea $(45 \% \mathrm{~N})$, Single superphosphate (18\% P, 16\% Ca, 8\% S) and Potassium chloride $\left(58 \% \mathrm{~K}_{2} \mathrm{O}\right)$.

Arugula seedlings were produced on expanded polystyrene trays ( 200 cells) with volume of $16 \mathrm{~mL}$ per cell, which received two seeds. Seedlings emerged 7 days after sowing (DAS) and, at 30 DAS, two seedlings were transplanted per pot and conducted until completing the cycle (51 DAS). The experiment used the arugula variety 'Cultivada', which has the following features: elongated leaves, lobed leaf blade, dark green color and spicy taste.

At 7, 14 and 21 days after transplantation (DAT), plants were evaluated for growth based on the number of leaves (NL), determined by counting the photosynthetically active leaves longer than $12 \mathrm{~cm}$, and plant height $(\mathrm{PH})$, measured as the distance from plant base to the tip of the most developed leaf.

At 21 DAT, gas exchanges were determined in the plants using an infrared gas analyzer, by measuring leaf transpiration 
rate $(\mathrm{E})$, intercellular $\mathrm{CO}_{2}$ concentration $(\mathrm{Ci})$, stomatal conductance (gs), and net $\mathrm{CO}_{2}$ assimilation rate (A). These data were used to determine water use efficiency (WUE), based on the relationship between A and E (Brito et al., 2012). Gas exchange measurements were taken from 7 to 9 a.m., in all plants, in a fully expanded leaf.

Still at 21 DAT, plants were collected to determine leaf area (LA) using a planimeter and leaf fresh phytomass (LFP), by weighing on analytical scale. After these analyses, the material was washed in running water and in water with detergent, undergoing double rinsing in deionized water. After washing, plants were placed in Kraft paper bags, identified with the respective treatments and dried in a forced-air oven $\left(60{ }^{\circ} \mathrm{C}\right)$ until constant weight. After this period, plants were again weighed to obtain leaf and root dry phytomass. Specific leaf area (SLA) was also determined, using the methodology described in Benincasa (2003).

The obtained data were subjected to analysis of variance by $\mathrm{F}$ test. For the factor irrigation depths, the F test $(\mathrm{p}<0.05)$ was conclusive since there were only two irrigation depths, whereas polynomial regression analysis was used for Si doses, with significance verified by the Student's t-test $(\mathrm{p}<0.05)$. Both cases used the program Sisvar 5.6 (Ferreira, 2011).

\section{Results AND Discussion}

The highest values for the number of leaves and plant height were obtained in plants cultivated under 100\% ETr in all periods evaluated (Figure 1A and B); for Si doses, no significant effect was observed. This may have occurred due to the short cycle of arugula, which is insufficient to express the effect of Si regarding the protection against water stress.

An analysis of arugula gas exchanges (Figure 2) evidenced the effect of the interaction between irrigation depths and $\mathrm{Si}$ doses on stomatal conductance (gs), $\mathrm{CO}_{2}$ assimilation rate (A) and instantaneous water use efficiency (WUE). For transpiration, there was an isolated effect of the applied doses of Si (Figure 2).

For the intercellular $\mathrm{CO}_{2}$ concentration $(\mathrm{Ci})$, there were differences only between the irrigation depths, and its highest values occurred when plants were cultivated under $100 \%$ ETr irrigation depth, on the order of $256.2 \mathrm{mmol}$ of $\mathrm{CO}_{2} \mathrm{~m}^{2}$, which was $2.6 \%$ higher than the value obtained under $50 \% \mathrm{ETr}$ irrigation depth, $249.6 \mathrm{mmol} \mathrm{CO}_{2} \mathrm{~m}^{2}$. However, these values

A.

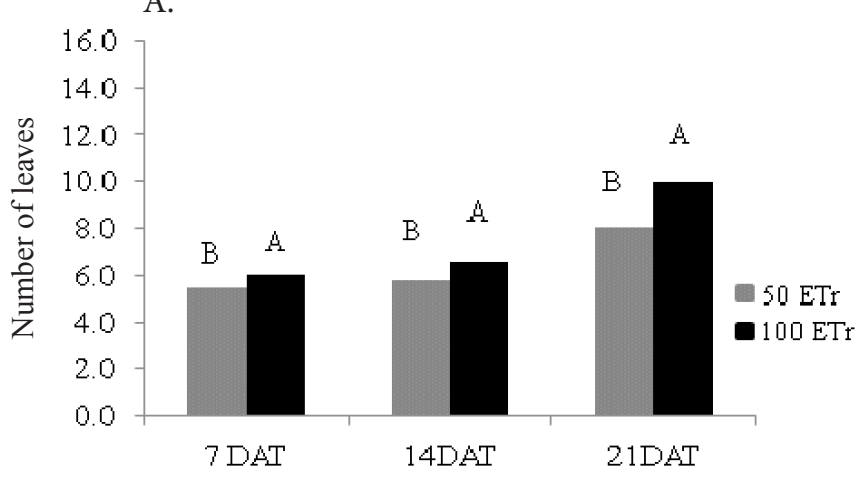

Days after transplantation (DAT) are equivalent to those obtained in $\mathrm{C}_{3}$ plants (Taiz et al., 2017), which indicates that there was no limitation to $\mathrm{CO}_{2}$ availability to perform photosynthesis.

Leaf transpiration rate (E) differed between the irrigation depths, with values of 3.55 and $4.02 \mathrm{mmol}$ of $\mathrm{H}_{2} \mathrm{O} \mathrm{m} \mathrm{m}^{-2} \mathrm{~s}^{-1}$, respectively, at the lowest and highest irrigation depths applied (50 and 100\% ETr). For the effect of Si (Figure 2A), the increase in the applied dose led to increment in transpiration on the order of 4.2 for every increase of $50 \mathrm{mg} \mathrm{L}^{-1}$ in Si concentration.

Gas exchange variables, stomatal conductance (gs) and photosynthetic rate (A), showed significant differences between treatments, with effect of the interaction between both water situations and Si doses (Figure $2 \mathrm{~B}$ and D) to which plants were subjected. Highest values of stomatal conductance occurred in plants under $100 \% \mathrm{ETr}$, but there was no effect of the increase in Si doses. However, when plants were under water limitation, receiving only $50 \% \mathrm{ETr}$, the estimated Si dose of $110 \mathrm{mg} \mathrm{dm}^{-3}$ led to reduction in the effect of water limitation on stomatal conductance.

Such restriction in transpiration and stomatal conductance tended to limit the net photosynthesis (Figure 2D), and the lowest values of $\mathrm{CO}_{2}$ assimilation rate were found in plants irrigated with $50 \%$ ETr. However, as for stomatal conductance, Si doses promoted reduction of the stress and it was possible to observe an increment in the values of net photosynthesis up to the estimated dose of $102 \mathrm{mg} \mathrm{L}^{-1}$, which is interesting because, this estimated photosynthesis value of $14.14 \mu \mathrm{mol} \mathrm{CO} \mathrm{m}^{-2} \mathrm{~s}^{-1}$ was slightly lower than the average photosynthesis observed in plants irrigated with $100 \% \mathrm{ETr}\left(15.2 \mu \mathrm{mol} \mathrm{CO} \mathrm{m}^{-2} \mathrm{~s}^{-1}\right)$. This effect of water stress had already been reported by Cechin et al. (2010), who observed reduction the physiological variables photosynthesis, stomatal conductance and transpiration of sunflower leaves due to water stress. In addition, as observed in other studies (Moro et al., 2015; Teodoro et al., 2015), Si has played fundamental role in the improvement of physiological aspects in plants.

Since gas exchanges are regulated by stomatal movement, the absorption of external $\mathrm{CO}_{2}$ depends on a higher transpiration, notably in $\mathrm{C}_{3}$ plants. Thus, reduction in transpiration limits the entry of carbon in the substomatal chamber (Shimazaki et al., 2007). Hence, plants need to have higher water use efficiency, i.e., absorb as much $\mathrm{CO}_{2}$ as possible with minimum water loss (Taiz et al., 2017), which occurred with arugula plants under stress and receiving the estimated Si dose of $74.3 \mathrm{mg} \mathrm{L}^{-1}$

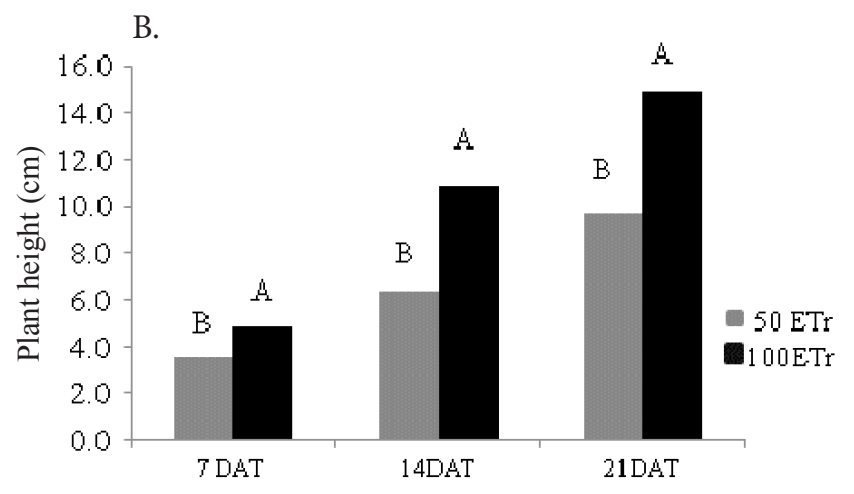

Figure 1. Number of leaves (A) and plant height (B) $(\mathrm{cm})$ at 7, 14 and 21 days after transplantation (DAT) in arugula plants cultivated under water stress, 50\% ETr irrigation depth and 100\% ETr irrigation depth, and silicon doses 
A.

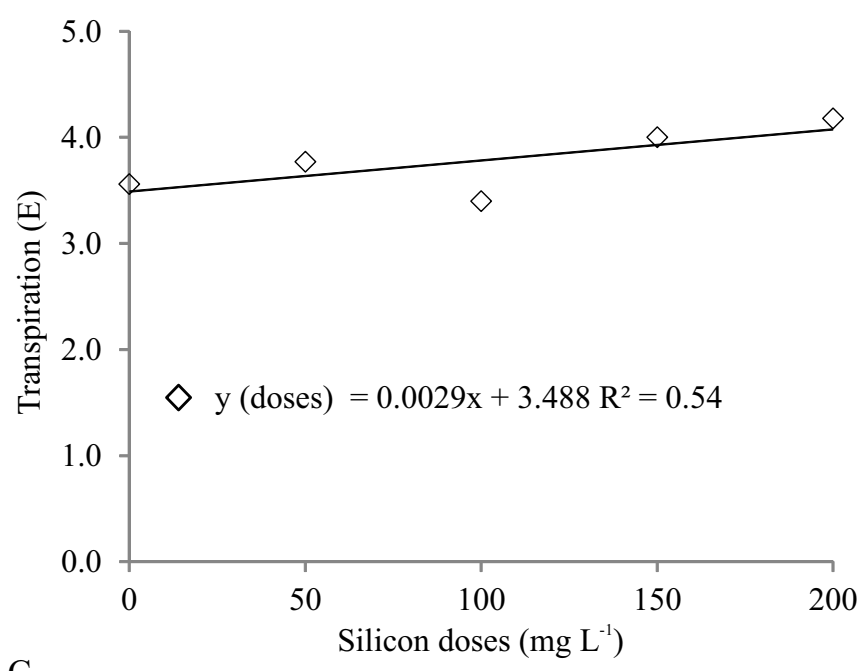

C.

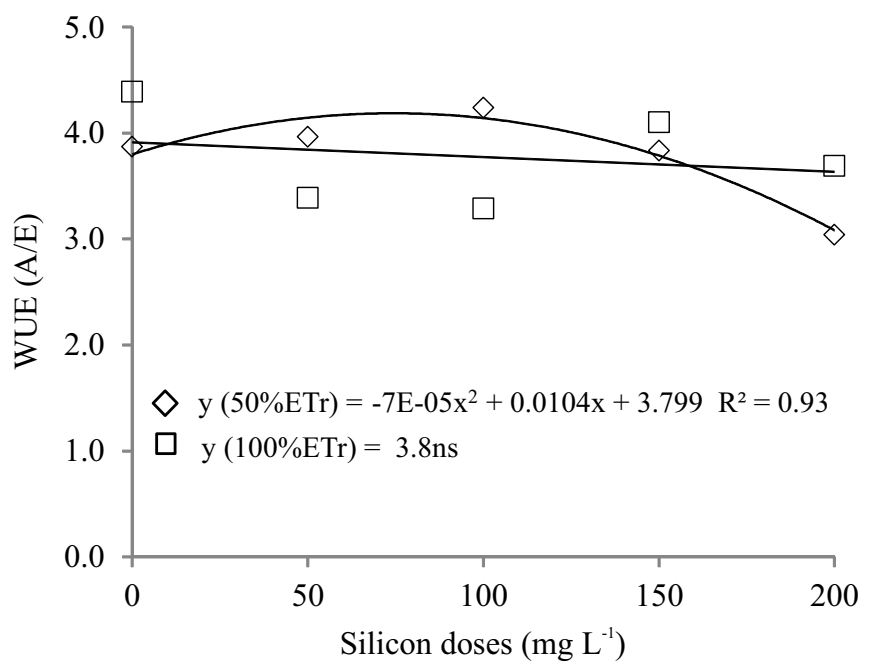

B.
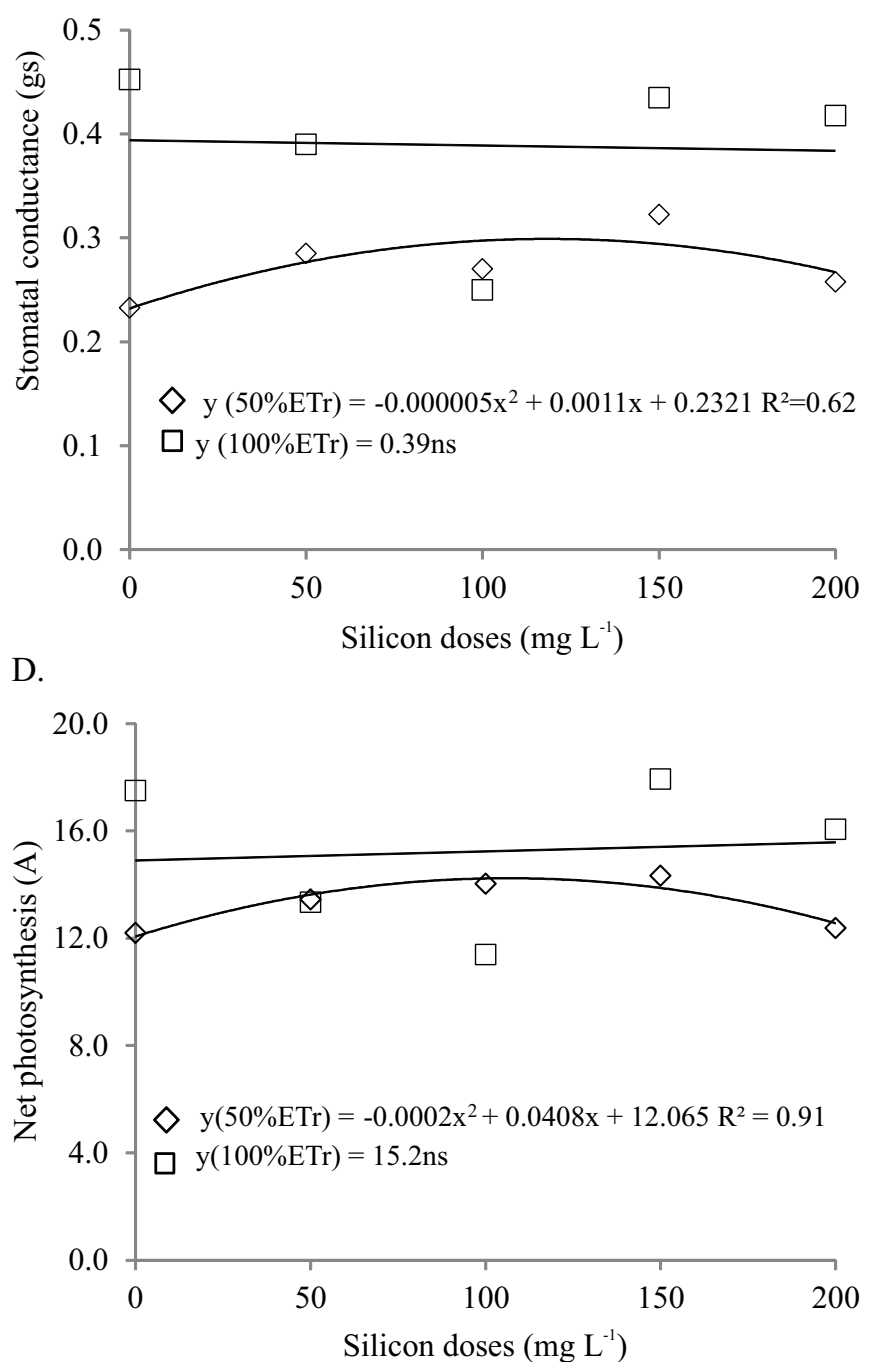

Figure 2. Leaf transpiration rate (A), stomatal conductance (B), water use efficiency (C) and photosynthesis (D) in arugula plants cultivated under water stress, 50\% ETr irrigation depth and 100\% ETr irrigation depth, and silicon doses, at 21 days after transplantation (DAT)

(Figure 2C), which showed WUE values higher than those of plants irrigated with $100 \%$ ETr, confirming the theory that Si promotes improvement in the process of transpiration and increases the efficiency of the plants.

It should be highlighted that $\mathrm{Si}$ is accumulated in epidermal cells and, in stomatal walls, it is found in the form of $\mathrm{H}_{4} \mathrm{SiO}_{4}$ (monosilicic acid). Hence, when the plant starts losing water, the monomeric form of Si transforms into the polymeric form, i.e., Si starts forming heavier chains of polysilicic acid. After polymerized, there is a decrease in the flexibility of stomatal walls and the trend is to remain closed, reducing transpiration and water loss (Luz et al., 2006) and causing the increase in water use efficiency.

For leaf dry phytomass, there were differences between the irrigation depths, with higher means observed in plants under irrigation with $100 \% \mathrm{ETr}$, on the order of $18.2 \mathrm{~g}$, which was $50 \%$ higher than the value observed in plants irrigated with $50 \% \mathrm{ETr}$. Under these circumstances, photosynthesis decreases, and it may lead to lower development and, consequently, lower biomass of arugula plants cultivated under 50\% ETr irrigation depth.

For leaf fresh phytomass and root dry phytomass (LFP and RDP) (Figure 3), there were effects of the interaction between treatments, and the highest values were observed in plants under the highest irrigation depth (100\% ETr) combined with the Si applications of 57 and $50 \mathrm{mg} \mathrm{L}^{-1}$, respectively (Figure $3 \mathrm{~A}$ and B). When 50\% ETr irrigation depth was applied, there was no effect of the increment in Si doses on these variables, but effects on physiological variables were observed when plants were under stress.

Similar behaviors were observed in total dry phytomass and leaf area of arugula plants, at 21 DAT, when significant interaction occurred between irrigation depths and Si doses. Highest means of leaf area (Figure 3C) were found in plants cultivated under $100 \%$ ETr, combined with Si dose of $41.7 \mathrm{mg} \mathrm{L}^{-1}$. For total dry phytomass (Figure 3D), there was also higher phytomass accumulation at the $100 \%$ ETr irrigation depth, but combined with the estimated Si dose of $0.5 \mathrm{mg} \mathrm{L}^{-1}$.

Regarding the ratio between shoot and root dry phytomass (shoot/root ratio) (Figure 3E), there was also effect of the interaction between the studied factors, with highest values promoted by the $100 \%$ ETr irrigation depth. However, for the effect of $\mathrm{Si}$, a quadratic behavior occurred when combined with the $100 \%$ ETr irrigation depth, with maximum ratio at the Si dose of $120.8 \mathrm{mg} \mathrm{L}^{-1}$, whereas plants under $50 \% \mathrm{ETr}$ 
A.

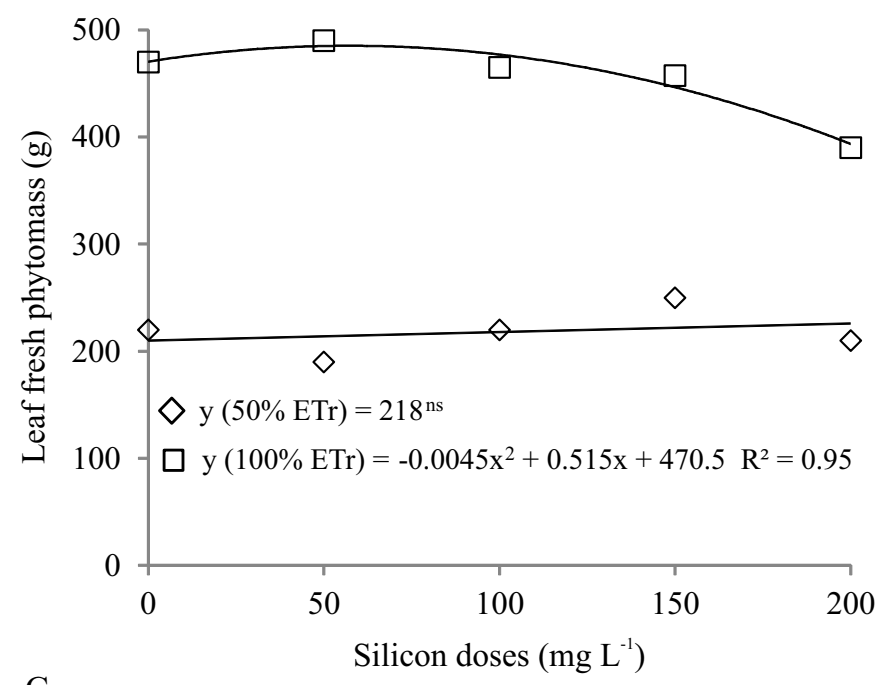

C.

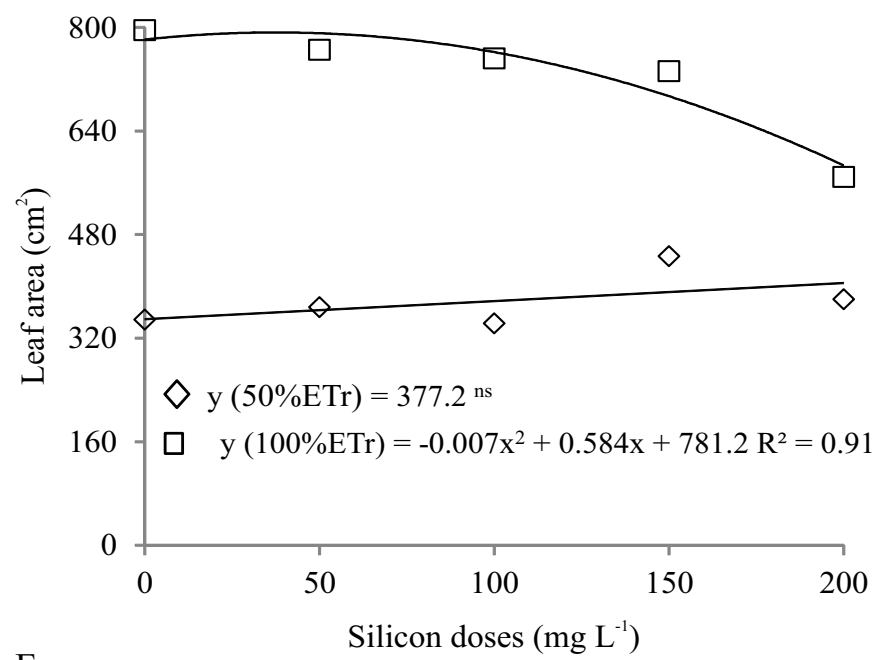

E.

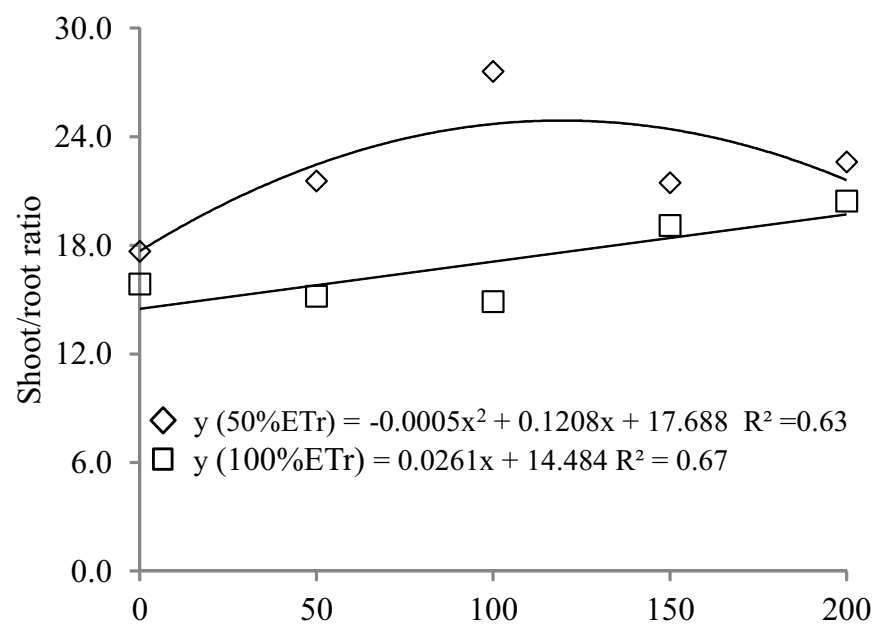

Silicon doses $\left(\mathrm{mg} \mathrm{L}^{-1}\right)$
B.

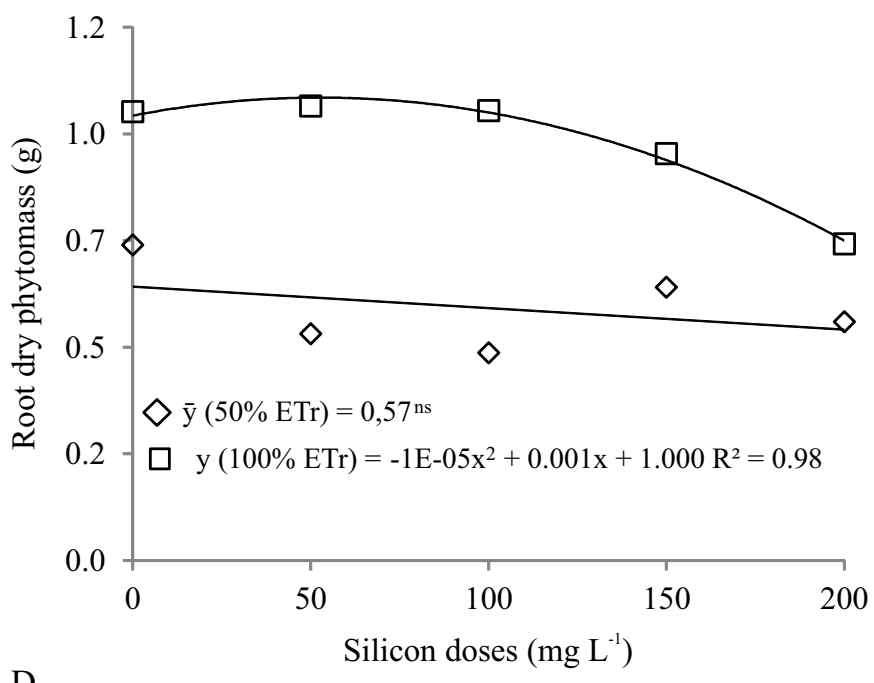

D.

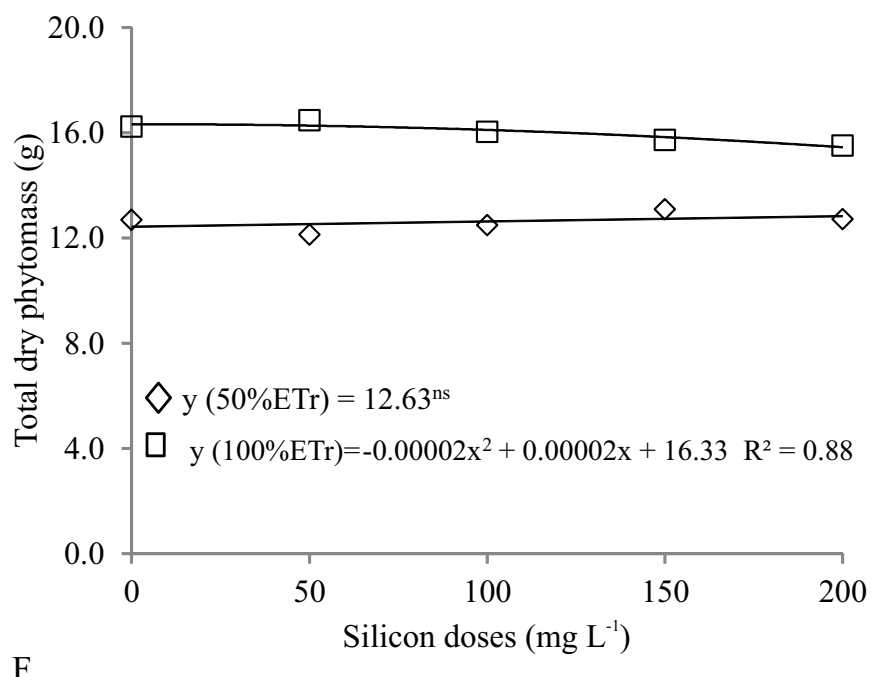

F.

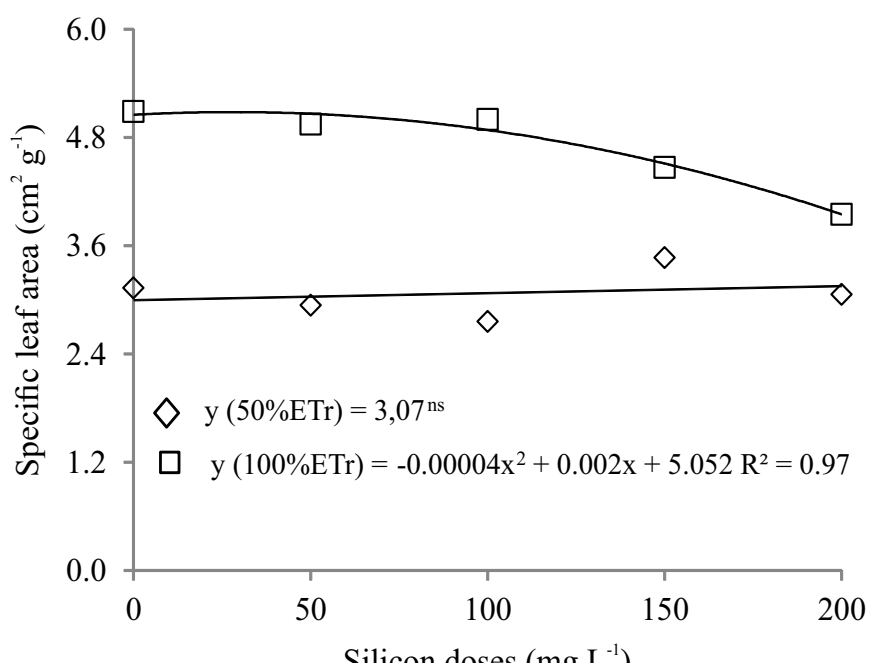

Figure 3. Leaf fresh phytomass (A), root dry phytomass (B), leaf area (C), total dry phytomass (D), shoot/root ratio (E) and specific leaf area (F) of arugula plants cultivated under water stress, 50\% ETr irrigation depth and 100\% ETr irrigation depth, and silicon doses, at 21 days after transplantation (DAT)

irrigation depth showed linear increase in the ratio as the $\mathrm{Si}$ dose increased. It should be noted that, in all situations, the values were higher than 1 , which means that the biomass formation in the shoots is prioritized over that in the roots. On the other hand, in the case of arugula, the increment in shoot phytomass caused by Si improves the quality of the final product, i.e., arugula leaves. Thus, it is interesting to introduce Si doses to improve the production.

For specific leaf area (SLA), there was significant statistical interaction (Figure $3 \mathrm{~F}$ ), and the best results occurred in plants 
cultivated under $100 \%$ ETr combined with the estimated Si dose of $25 \mathrm{mg} \mathrm{L}^{-1}$ (Figure 3F). Under water stress condition, there was no significant effect of the increment in Si doses.

\section{Conclusions}

1. Higher values for the number of leaves and plant height were obtained in plants cultivated under $100 \% \mathrm{ETr}$.

2. Silicon application with estimated doses between 100 and $120 \mathrm{mg} \mathrm{L}^{-1}$ promotes improvements in the gas exchanges of arugula plants under water stress.

3. Silicon application with doses between 30 and $60 \mathrm{mg} \mathrm{L}^{-1}$ in arugula plants under $100 \%$ ETr irrigation allows greater phytomass formation.

\section{Literature Cited}

Benincasa, M. M. P. Análise de crescimento de plantas (noções básicas). 2.ed. Jaboticabal: FUNEP, 2003. 41p.

Brito, M. E. B.; Soares, L. A. dos A.; Fernandes, P. D.; Lima, G. S. de; Sá, F. V. da S.; Melo, A. S. de. Comportamento fisiológico de combinações copa/porta-enxerto de citros sob estresse hídrico. Revista Brasileira de Ciências Agrárias, v.7, p.857-865, 2012. https://doi.org/10.5039/agraria.v7isa1941

Cechin, I.; Corniani, N.; Fumis, T. F.; Cataneo, A. C. Differential responses between mature and young leaves of sunflower plants to oxidative stress caused by water deficit. Ciência Rural, v.40, p.12901294, 2010. https://doi.org/10.1590/S0103-84782010000600008

EMBRAPA - Empresa Brasileira de Pesquisa Agropecuária. Centro Nacional de Pesquisa de Solos. Manual de métodos de análise de solo. 2.ed. Rio de Janeiro: Embrapa, 1997. 212p.

Ferreira, D. F. Sisvar: A computer statistical analysis system. Ciência e Agrotecnologia, v.35, p.1039-1042, 2011. https://doi.org/10.1590/ S1413-70542011000600001

Luz, J. M. Q.; Guimarães, S. T. M. R.; Korndörfer, G. H. Produção hidropônica de alface em solução nutritiva com e sem silício. Horticultura Brasileira, v.24, p.295-300, 2006. https://doi. org/10.1590/S0102-05362006000300005
Ma, J. F.; Yamaji, N. Silicon uptake and accumulation in higher plants. Trends in Plant Science, v.11, p.392-397, 2006. https://doi. org/10.1016/j.tplants.2006.06.007

Malavolta, E.; Vitti, G. C.; Oliveira, S. A. Avaliação do estado nutricional das plantas: Princípios e aplicações. 1.ed. Piracicaba: Potafos, 1997. 319p.

Moro, A. L.; Broetto, F.; Moro, E. Relação hídrica e teor de clorofila em dois cultivares de arroz submetido à deficiência hídrica e adubação silicatada. Irriga, v.20, p.570-586, 2015. https://doi.org/10.15809/ irriga.2015v20n3p570

Porto, R. de A.; Silva, E. M. B.; Souza, D. S. de M.; Cordova, N. R. M.; Polizel, A. C.; Silva, T. J. A. da. Adubação potássica em plantas de rúcula: Produção e eficiência no uso da água. Revista Agro@mbiente, v.7, p.28-35, 2013.

Rodrigues, F. de A.; Oliveira, L. A. de; Korndörfer, A. P.; Korndörfer, G. H. Silício: Um elemento benéfico e importante às plantas. Informações Agronômicas, v.134, p.14-20, 2011.

Shimazaki, K.; Doi, M.; Assmann, S. M.; Kinoshita, T. Light regulation of stomatal movement. Annual Review of Plant Biology, v.58, p.219-247, 2007. https://doi.org/10.1146/annurev. arplant.57.032905.105434

Souza, L. de C.; Siqueira, J. A. M.; Silva, J. L. de S.; Coelho, C. C. R.; Neves, M. G.; Oliveira Neto, C. F. de. Osmorreguladores em plantas de sorgo sob suspensão hídrica e diferentes níveis de silício. Revista Brasileira de Milho e Sorgo, v.12, p.240-249, 2013. https://doi.org/10.18512/1980-6477/rbms.v12n3p240-249

Souza Neta, M. L. de; Oliveira, F. de A. de; Silva, R. T. da; Souza, A. A. T.; Oliveira, M. K. T. de; Medeiros, J. F. de. Efeitos da salinidade sobre o desenvolvimento de rúcula cultivada em diferentes substratos hidropônicos. Revista Agro@mbiente, v.7, p.154-161, 2013.

Taiz, L.; Zeiger, E.; Møller, I. M.; Murphy, A. Fisiologia e desenvolvimento vegetal. 6.ed. Porto Alegre: Artmed, 2017. 858p.

Teodoro, P. E.; Ribeiro, L. P.; Oliveira, E. P. de; Corrêa, C. C. G.; Torres, F. E. Acúmulo de massa seca na soja em resposta a aplicação foliar com silício sob condições de déficit hídrico. Bioscience Journal, v.31, p.161-170, 2015. https://doi.org/10.14393/BJv31n1a2015-22283 